\title{
NOTES ON BOOKS
}

Aids to Bacteriology, by William Partridge, F.I.C., fifth edition. (Baillière, 5s.) An informative little volume, brought well up to date, designed to meet the needs of those who, their interest in bacteriology being determined by the exigencies of examinations, seek knowledge in tabloid form.

In Asthma and its Treatment, Dr Percy Hall (Heinemann, 7s. 6d.) explains the wide outlook required and the many angles from which each individual case of asthma must be approached. Whilst touching briefly on all the possible lines of treatment he particularly stresses the value of physio-therapy. In his hands ultra-violet light appears to be a much more powerful weapon in asthma than is generally found.

Elementary Zoology for medical students, second edition, by L. A. Borradaile, Sc.D. (Humphrey Milford, ros. 6d.). The first edition of this book appeared in 1923 , and it is recognised as a most trustworthy text-book on the subject. The new edition is welcomed. It shows evidence of careful revision, and an account of mosquito, house-fly, and tape-worm have been added. The book can be strongly recommended to students and all interested in zoology.

The Treatment of Skin Diseases, by Noxon Toomey, M.D., B.A. (Lister Medical Press). If one should want to get a comprehensive pharmacopœia for use in dermatology, this book can be thoroughly recommended. The plethora of agents used is rather confusing, although the author does indicate occasions for their use-at times clearly, at other times very casually-and he points out that "all available procedures need not be carried out in every case." There is, however, a fund of knowledge, written by a man of rich experience that rewards the reader.

The Physiological Principles of Hydrology, by R. G. Gordon, M.D., and F. G. Thomson, M.D. (Cape, 5s.), discusses the physiology of the skin, circulation, metabolism, etc., in relation to the uses of waters. An account is given of the effects derived from the internal administration of mineral waters, taking these up according to their constituents and giving a list of the various types of waters in different European countries. The last chapter aims at giving an account of the manner in which different diseases may be treated by hydrology.

Greek Medicine. Extracts illustrative of medical writers from Hippocrates to Galen, translated and annotated by Arthur J. Brock, M.D. (Dent, 5 s.), form one of the Library of Greek Thought, edited by Ernest Barker. It gives six extracts from Hippocrates, including the 


\section{Notes on Books}

Hippocratic oath and several surgical extracts; Thucydides's description of the pestilence at Athens; a few paragraphs from Plato, Aristotle, and Rufus of Ephesus; and sixteen longer extracts from Galen. The reader who is anxious to obtain a general idea of Greek medicine will find these extracts admirably selected and translated.

An Introduction to the Study of Physic, by William Heberden, edited with a prefatory essay by Leroy Crummer, M.D. (Oxford University Press, Ios.). William Heberden, who lived from I 710 to $180 \mathrm{I}$, practised in London during the eighteenth century. The editor describes how he picked up the manuscript, now published for the first time, in a London second-hand book-shop, and was surprised to find that the handwriting was identical with that of letters from Heberden in various libraries. The "Introduction" runs to some seventy small printed pages, and describes what the student of that time need know of botany, chemistry, anatomy, institutions of medicine, etc. Anyone desiring to obtain a clear picture of the scope of medicine in the eighteenth century could not do better than peruse this little volume.

Intermediate Physics, by R. A. Houstoun (Longmans, Ios. 6d.). This work deals with the subject under the usual headings, and each section, excepting that on Sound, has already been published separately (1905-1929). The present combination presents the science in a thorough and comprehensive manner, and the author is to be congratulated in having succeeded in the aim referred to in his Preface-that of making the treatment clear and attractive.

A Manual of Normal Physical Signs, by Wyndham B. Blanton, B.A., M.A., M.D. Second edition. (Kimpton, r2s. 6d.). The author, who writes from Virginia, aims at giving the beginner a clear description of the normal findings in the examination of a healthy individual. The text of the chapters is arranged in note-book form. It provides a short description of the methods of examination and what amounts to a list of all the possible examinations that can be carried out. The book contains many valuable hints of a practical nature, but covers so extensive a field that the student may have difficulty in seeing the wood for the trees.

A Treatise on Light, by R. A. Houston (Longmans, Green, I2s. 6d.). It is stated by the author in the preface to the present new and revised edition of his Treatise on Light, that the book deals with the full scope of the subject, and includes the results of recent investigations. It is thus not an elementary work, and involves a thorough knowledge of elementary mathematics, and some acquaintance with the calculus. 


\section{Books Received}

In addition to a detailed treatment of the more familiar parts of the subject, sections are devoted to such eminently practical matters as lamps and illumination, and ultra-violet and X-radiations, while the concluding chapter presents an outline of present knowledge regarding the ether and relativity. The numerous editions through which the work has already passed provide a sufficient recommendation.

In Individual Diagnosis, by F. G. Crookshank, M.D., F.R.C.P. together Paul, Trench, Trubner \& Co., 2s. 6d.), the author has brought "Organ-Ja lectures entitled "Diagnosis and the Syndrome" and once again to." In a rather obscure manner an attempt is made a distinct and living entity with personal desires and special aims peculiar to himself. Before a broad diagnosis can be established, psychological values must be considered as well as any associated pathological background. We believe that medical men are accustomed to do this-consciously or unconsciously-every day, and there is little of definite assistance offered to them in this book.

\section{BOOKS RECEIVED}

$\mathrm{B}_{\mathrm{ACH}}$, Dr Hugo. The Quartz Lamp.

Clendening, (The Sollux Publishing Co., Slough) Ios. 6d. net.

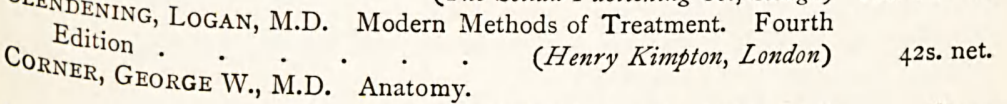

DAWSON, WARPN (Paul B. Hoeber, Inc., New York) \$1.50

FulTon, Jown (Paul B. Hoeber, Inc., New York) \$r.50

GARROD, ARChinl B. Hoeber, Inc., New York) The Inchibald E., K.C.M.G., D.M., LL.D., F.R.C.P., F.R.S. The Inborn Factors in Disease.

$\mathrm{H}_{\mathrm{ADFIELD}}$ (Humphrey Milford, Oxford University Press, London) Anær, Charles F., M.B.E., M.A., M.D. (Camb.). Practical

Anæsthetics. Second Edition. (Baillière, Tindall \& Cox, London) Child, ROBERT, M.D., F.R.C.P. Lectures on Diseases of

Interildren. Sixth Edition . (Edward Arnold \& Co., London) (Fifh Year).

KAPLAN, IRA I., B.S., M.D. Practical Radiation Therapy. (Allen \& Unwin, Ltd., London) 24s.,

LEJARS, FELIX Coctical Radiation Therapy.
(W.B. Saunders Company, London)

$\$ 1.50$

7s. 6d. net.

7s. 6d. net.

2Is. net.

oth $32 \mathrm{~s}$.

(Jonathan Cape, London) $\quad 50 s$. net. 